Monika PŁaziak, Anna Irena Szymańska

Uniwersytet Pedagogiczny w Krakowie, Polska - Pedagogical University of Cracow, Poland

\title{
Czynniki warunkujące atrakcyjność dokonywania zakupów na placach targowych Krakowa
}

\author{
Conditions of the Attractiveness of Purchases at the Markets in Cracow
}

Streszczenie: Artykuł prezentuje diagnozę preferencji konsumentów w zakresie najczęściej wybieranych miejsc dokonywania zakupów, skategoryzowanych według form prowadzonego handlu. Wskazano w nim również czynniki warunkujące decyzje o wyborze placu targowego na miejsce dokonywania zakupów. $\mathrm{W}$ tym celu przeprowadzono badania bezpośrednie $\mathrm{z}$ wykorzystaniem kwestionariusza wywiadu, które objęły swoim zasięgiem 22 place targowe zlokalizowane w obszarze granic administracyjnych miasta Krakowa. Badania prowadzone były w wyznaczonych punktach miasta - powszechnie uczęszczanych oraz charakteryzujących się znaczną bliskością położenia względem badanych targowisk. W badaniach uczestniczyło 502 respondentów, w przeważającej części będących mieszkańcami Krakowa. Uzyskane wyniki badań pozwalają domniemywać, że głównymi przesłankami towarzyszącymi zakupom na placach targowych są: aspekt zdrowotny (megatrend w zachowaniach konsumentów polegający na coraz większej koncentracji na zdrowym odżywianiu) i aspekt ekonomiczny. Klienci placów targowych szukają produktów świeżych, zdrowych i niewytwarzanych hurtowo, a także tanich.

\begin{abstract}
In the article authors present the diagnosis of consumer preferences in terms of the most popular shopping destinations, categorized according to the forms of trade. Also there is an indication of the factors of the choice of markets as a place of purchases. For that purpose, the research was carried out with the use of a questionnaire interview. The research concerned 22 markets located in Cracow. The survey was conducted in the indicated places of the city - widely attended and characterized by a considerable proximity to the markets. 502 respondents took part in the survey. In the majority they were residents of Cracow.The obtained results allow to presume that the main premise accompanying purchases at the markets are two factors: the health aspect (megatrend of the consumers' behavior as a growing focus on healthy diet) as well as the economic aspect. Consumers at markets look for fresh, healthy, non-wholesale produced, but also cheap products.
\end{abstract}

Słowa kluczowe: handel; Kraków; place targowe; preferencje; przedsiębiorca; targowiska; zachowania konsumentów; zakupy

Key words: consumer behaviour; Cracow; entrepreneur; markets; preferences; purchases; trade

Otrzymano: 20 listopada 2015

Received: 20 November 2015

Zaakceptowano: 16 marca 2016

Accepted: 16 March 2016 


\section{Sugerowana cytacja/Suggested citation:}

Płaziak, M., Szymańska, A. (2016). Czynniki warunkujące atrakcyjność dokonywania zakupów na placach targowych Krakowa. Przedsiębiorczość - Edukacja, 12, 217-232.

\section{Wstęp}

Artykuł w pierwszej części obejmuje krótką charakterystykę sytuacji handlu targowiskowego w Polsce i Krakowie w ujęciu historycznym oraz współczesnym. Natomiast część zasadnicza zawiera opis i wnioski badań empirycznych dotyczących preferencji mieszkańców Krakowa w zakresie dokonywania zakupów według różnych form handlu, ze szczególnym uwzględnieniem placów targowych. W analizach wzięto pod uwagę strukturę wiekową respondentów.

Zasadniczym celem badań była identyfikacja czynników warunkujących decyzje respondentów o wyborze placu targowego jako miejsca dokonywania zakupów lub braku takich decyzji. Postawiono dwa pytania badawcze:

1. Czy i w jaki sposób struktura wieku respondentów wiąże się z preferencjami zakupowymi w zakresie najczęściej wybieranych form handlu?

2. Jakie są powody (czynniki) wyboru placów targowych jako miejsca dokonywania zakupów (lub braku tego wyboru) wśród respondentów?

Ponadto analiza objęła częstotliwość odwiedzin placów targowych przez respondentów oraz preferencje w zakresie nabywanych tam produktów. Dokonano również oceny zmian, które w opinii ankietowanych zaszły na placach targowych w ciągu ostatnich lat.

\section{Specyfika handlu targowiskowego w Polsce}

Place targowe, zwane również targowiskami, od zarania stanowią nierozerwalny fragment polskich miast. Dawniej zlokalizowane były w samych centrach miast i miasteczek, czyli w rynkach miejskich. Właśnie tam w specjalnie wyznaczone dni targowe odbywały się targi. Na placach toczyło się życie codzienne mieszkańców i przybyszów, kwitł miejski handel, funkcjonowało rzemiosło. Lokalizowano tam kramy kupieckie, jatki, a nawet sukiennice. W wielu przypadkach to właśnie funkcje targowe stały się zalążkiem centralnego miejsca w osadzie, a następnie tworzącego się tam miasta. Przyczynił się do tego fakt, że w średniowieczu miasta i miasteczka targowe uzyskiwały specjalne przywileje, co dawało możliwość rozwoju tych miejscowości oraz przynosiło zyski zarówno mieszkańcom, jak i władzom miejskim pobierającym opłaty targowe. Niektóre miejscowości uzyskały swoje nazwy związane z funkcjami targowymi lub dniami, w których targi się odbywały, np. Nowy Targ, Targowica, Targowisko, Targowiska, Środa Śląska, Piątek i in. W przestrzeni ukształtowanego już miasta plac targowy był miejscem, gdzie zazwyczaj znajdował się ratusz miejski.

Jednakże, w wielu miastach, wraz z zapotrzebowaniem na większą powierzchnię handlową oraz celami reprezentacyjnymi rynku funkcje targowe przenoszono do innych miejsc. Choć nie były to tak prestiżowe lokalizacje jak poprzednie, handel targowiskowy nadal kwitł, a targowiska współtworzyły charakter przestrzeni miast.

W okresie II Rzeczypospolitej odbywały się tzw. targi gminne. Określano nimi targi odbywające się w lokalach oraz innych miejscach urządzonych przez gminę w formie targowiska. 
Zasady organizacji i prowadzenia tych targów, które dzielono na targi małe (zwykłe i tygodniowe) i targi wielkie (powiatowe, wojewódzkie, odpustowe, kiermasze i jarmarki), poddano ścisłej reglamentacji prawnej. Podstawowym warunkiem, którego spełnienie umożliwiało zorganizowanie i prowadzenie targowiska jako miejsca odbywania się targów gminnych, było uzyskanie przez gminę uprawnień targowych (Szafrański, 2002).

W Polsce w okresie gospodarki centralnie sterowanej place targowe funkcjonowały stosunkowo dobrze. To tam można było dostać produkty niedostępne w ubogo zaopatrzonych sklepach, także towary przemycane zza żelaznej kurtyny.

Intensywny rozwój handlu na targowiskach nastąpił ponownie wraz z początkiem transformacji ustrojowej i społeczno-ekonomicznej po 1989 r. Zaznaczył się wówczas ogólny wzrost aktywności handlowej Polaków. Zmieniały się ich potrzeby zakupowe oraz lawinowo rosła różnorodność towarów produkowanych w kraju i dostępnych z zagranicy. Na masową skalę pojawiło się zjawisko tzw. turystyki handlowej - zza wschodniej granicy Polski przybywały osoby handlujące różnorodnym asortymentem. Kilka lat później Polska stała się krajem, do którego masowo przyjeżdżali Rosjanie, Białorusini, Ukraińcy i Litwini, dokonujący zakupów w sklepach. Jednocześnie notowano bardzo częste przyjazdy Niemców, którzy jako miejsce dokonywania zakupów wybierali zwłaszcza bazary (Kropiwnicki, 2003; Powęska, 2002).

Najsłynniejszym targowiskiem tamtych czasów był Stadion Dziesięciolecia, wybudowany w 1955 r., na którym do końca epoki PRL-u odbywały się najważniejsze imprezy sportowe w kraju. W zamian za utrzymanie obiektu stadion został w 1989 r. wydzierżawiony przez miasto stołeczne Warszawa do celów handlowych firmie Damis, która założyła na jego koronie „Jarmark Europa", liczący ponad 5 tys. podmiotów gospodarczych i będący wówczas jednym z największych targowisk Europy. Z pracy na Stadionie utrzymywało się ok. 250 tys. osób. W 1997 r. obroty targowiska wyniosły 1,9 mld zł, a wartość eksportu - 400 tys. USD. Stawiało to Stadion w rzędzie 5 największych przedsiębiorstw w Polsce. W Małopolsce natomiast zasłynął plac targowy Tomex znajdujący się w Krakowie - Nowej Hucie. Założono go w 1990 r. Liczył on ok. 700 punktów handlowych i 2 tys. podmiotów gospodarczych (Dzieszyński, Franczyk, 2006).

Rozwijające się w okresie transformacji bazary miały pewne znaczenie makroekonomiczne dla polskiej gospodarki, gdyż, jak pisze J. Kropiwnicki (2003), wywarły silny wpływ na wielkość polskiego eksportu oraz saldo obrotów bieżących z zagranicą, wpłynęły znacząco na wzbogacenie ofert dóbr na rynku, generowały miejsca pracy, odegrały ważną rolę w rozwoju sektora małych i średnich przedsiębiorstw, a także miały znaczący wpływ na produkcję dóbr i usług, a co za tym idzie - na wielkość PKB. Jednocześnie charakteryzowały się nagromadzeniem niekorzystnych zjawisk, takich jak patologie życia gospodarczego i społecznego, np. przemyt narkotyków i kradzionych samochodów, nielegalna imigracja, zorganizowana przestępczość.

Współcześnie większość placów targowych działa codziennie. Zwiększa się różnorodność asortymentowa: nie tylko rolnicy sprzedają na nich swoje płody rolne, a rzemieślnicy swoje wyroby, ale coraz częściej na terenie placów targowych znajdują się stałe, zadaszone stragany lub hale ze stoiskami, a także małe sklepy, w których handel jest prowadzony niekoniecznie przez właścicieli lub najemców obiektów, ale również przez pracowników.

\section{Place targowe jako przedmiot badań}

W literaturze przedmiotu w celu odróżnienia tradycyjnych placów targowych, na których w przeszłości obrót towarami związany był z odbywającym się targiem, od placów z handlem 
codziennym, o urozmaiconej strukturze sprzedawanych towarów i rodzaju obiektów handlowych, można znaleźć określenie bliższe realiom współczesnym - plac handlowy lub bazar (Gołąb-Korzeniowska, 1997). Biorąc jednakże pod uwagę fakt, że na niektórych placach nadal funkcjonuje określenie „dni targowe”, czyli dni, w których handel jest nieco wzmożony, oraz z racji współwystępowania form handlu prowadzonego przez rolników sprzedających własne plony i produkty, jak i rzemieślników handlujących własnymi wyrobami, oraz przedsiębiorców prowadzących regularną sprzedaż, na potrzeby niniejszego opracowania przyjęto terminologię: plac targowy, targowisko, plac handlowy i bazar. Nazwy te są traktowane jako synonimy i używane zamiennie.

Zgodnie z definicją Głównego Urzędu Statystycznego wyróżnia się targowiska i targowiska sezonowe. Targowiska są to „wyodrębnione tereny lub budowle (plac, ulica, hala targowa) ze stałymi, względnie sezonowymi punktami sprzedaży drobnodetalicznej lub urządzeniami przeznaczonymi do prowadzenia handlu, codziennie lub w wyznaczone dni tygodnia”. Natomiast za targowiska sezonowe uważa się „place i ulice, gdzie uruchamiane są na okres do 6 miesięcy punkty handlowe, w związku ze wzmożonym ruchem nabywców (np. nadmorski ruch urlopowy) i działalność ta jest ponawiana w kolejnych sezonach" (Rynek wewnętrzny w 2012 r., 2013). Niniejsze opracowanie odnosi się do pierwszego z powyższych pojęć, czyli targowisk.

Tematyka placów targowych, z uwagi na jej uniwersalny charakter, jest poruszana i stanowi przedmiot badań w ramach różnych dziedzin nauki. Geografowie w pracach poświęconych placom targowym koncentrują się głównie na funkcjach i roli targowisk w strukturze przestrzennej i ekonomicznej miast oraz regionów (Płaziak, Szymańska, 2015b; Płaziak, Szymańska, 2014; Powęska, 2002a; Werwicki, 2001; Zuzańska-Żyśko, Sitek, 2011). Ich badania dotyczą także turystyki handlowej oraz roli targowisk w przemianach zachodzących na obszarach przygranicznych (Powęska, 1995; Powęska, 2002b). Ekonomiści analizują najczęściej handel odbywający się na targowiskach jako element systemu ekonomicznego kraju, badają rolę szarej strefy w handlu targowiskowym oraz rozwój drobnej przedsiębiorczości, w tym - firm rodzinnych (Ciechomski, 2014; Dąbrowski, 1996; Peterlik, 2000; Tomalak, Wyżnikiewicz, 1999; Urban, Michałowska, 2013; Wojdacki, 2011). Architekci bardzo często rozpatrują miejsce placów targowych w układach urbanistycznych (Barek, 2010; Gołąb-Korzeniowska, 1995, 1997). Socjologowie natomiast w badaniach związanych z placami targowymi traktują te miejsca jako przestrzeń publiczną i rozpatrują zjawiska zachodzące w tej przestrzeni (Madanipour, 2003).

Analiza literatury tematu wskazuje na niewielką liczbę opracowań poświęconych zagadnieniom atrakcyjności dokonywania zakupów i prowadzenia handlu na placach targowych Krakowa. Niewiele napisano prac obejmujących badaniami wszystkie place targowe Krakowa (Dziechciarz, 1992a). Powstają raczej pojedyncze studia dotyczące wybranych placów, spośród których wymienić należy opracowania T. Dziechciarza (1992b) i Z. Szromba-Rysowej (1993). Częściej natomiast podejmowana jest tematyka dotycząca roli i znaczenia placów targowych w strukturze przestrzennej miasta. Na uwagę w tym zakresie zasługują prace M. Gołąb-Korzeniowskiej (Gołąb-Korzeniowska, 1995; 1997).

\section{Charakterystyka handlu targowiskowego w Krakowie}

W roku 2013 w Krakowie funkcjonowało 27 targowisk, z czego 16 znajdowało się na terenach należących do gminy, a 11 na terenach prywatnych (dane za rok 2013, na podstawie: Raport o stanie miasta 2013, 2014) (tab. 1). Natomiast targowisk sezonowych w roku 2012 zanotowano 1146 (Rocznik Statystyczny Krakowa 2013, 2013). 
Tab. 1. Place targowe Krakowa

\begin{tabular}{|c|c|c|c|c|}
\hline $\begin{array}{c}\text { Nazwa placu } \\
\text { targowego } \\
\text { (opcjonalne nazwy) }\end{array}$ & Lokalizacja & $\begin{array}{l}\text { Powierzchnia } \\
\qquad\left(\mathbf{m}^{2}\right)\end{array}$ & $\begin{array}{c}\text { Właściciel - } \\
\text { gmina miejska/ } \\
\text { prywatny }\end{array}$ & Dzielnica \\
\hline $\begin{array}{l}\text { Rynek Kleparski (Stary } \\
\text { Kleparz) }\end{array}$ & ul. św. Filipa & 6079 & gmina miejska & \multirow{4}{*}{$\begin{array}{c}\text { Dzielnica I Stare } \\
\text { Miasto }\end{array}$} \\
\hline Nowy Kleparz & ul. Długa & 4348 & gmina miejska & \\
\hline Plac Nowy & ul. Estery & 2855 & gmina miejska & \\
\hline Krakowskie Kwiaciarki & Rynek Główny & 310 & gmina miejska & \\
\hline $\begin{array}{l}\text { Unitarg (Hala } \\
\text { Targowa) }\end{array}$ & ul. Grzegórzecka & 5409 & gmina miejska & $\begin{array}{l}\text { Dzielnica II } \\
\text { Grzegórzki }\end{array}$ \\
\hline Plac Imbramowski & pl. Imbramowski & 21810 & gmina miejska & \multirow{2}{*}{$\begin{array}{c}\text { Dzielnica IV } \\
\text { Prądnik Biały }\end{array}$} \\
\hline Azory & ul. Chełmońskiego & 584 & gmina miejska & \\
\hline $\begin{array}{l}\text { Plac Nowowiejski } \\
\text { („Novum Plac”) }\end{array}$ & ul. J. Lea & 2206 & gmina miejska & \multirow{2}{*}{$\begin{array}{l}\text { Dzielnica V } \\
\text { Krowodrza }\end{array}$} \\
\hline Giełda Rotunda & ul. Oleandry & 1730 & prywatny & \\
\hline Plac Rydla & $\begin{array}{c}\text { ul. Młodej Polski } \\
\text { i Jadwigi z Łobzowa }\end{array}$ & 1813 & gmina miejska & \multirow{2}{*}{$\begin{array}{l}\text { Dzielnica VI } \\
\text { Bronowice }\end{array}$} \\
\hline $\begin{array}{l}\text { Plac Targowy KPPU } \\
\text { (Centrum Giełdowo- } \\
\text {-Handlowe Balicka) }\end{array}$ & ul. Balicka & 80602 & prywatny & \\
\hline Plac na Stawach & ul. Senatorska & 3211 & gmina miejska & $\begin{array}{l}\text { Dzielnica VII } \\
\text { Zwierzyniec }\end{array}$ \\
\hline Rynek Dębnicki & Rynek Dębnicki & 1599 & gmina miejska & $\begin{array}{c}\text { Dzielnica VIII } \\
\text { Dębniki } \\
\end{array}$ \\
\hline Targowisko Borek & ul. Orzechowa & 4802 & prywatny & $\begin{array}{l}\text { Dzielnica IX } \\
\text { Łagiewniki - } \\
\text { Borek Fałęcki }\end{array}$ \\
\hline Manhattan & ul. Białoruska & 3120 & prywatny & \multirow{2}{*}{$\begin{array}{l}\text { Dzielnica } \\
\text { XI Podgórze } \\
\text { Duchackie }\end{array}$} \\
\hline Beskidy & ul. Beskidzka/Witosa & 3360 & prywatny & \\
\hline Targowisko & ul. Na Kozłówce & 744 & gmina miejska & \multirow{2}{*}{$\begin{array}{c}\text { Dzielnica XII } \\
\text { Bieżanów - } \\
\text { Prokocim } \\
\end{array}$} \\
\hline $\begin{array}{l}\text { Jerzmanowskiego - } \\
\text { Nowy Prokocim }\end{array}$ & ul. E. Jerzmanowskiego & 3820 & prywatny & \\
\hline Tandeta & ul. Krzywda & 26312 & prywatny & \multirow{4}{*}{$\begin{array}{l}\text { Dzielnica XIII } \\
\text { Podgórze }\end{array}$} \\
\hline King & ul. Krzywda & 3584 & prywatny & \\
\hline Efekt SA & ul. Półłanki & 72590 & prywatny & \\
\hline Centrum - Kalicki & ul. Ch. Botewa & 2200 & prywatny & \\
\hline Złoty Wiek & $\begin{array}{c}\text { ul. ks. K. Jancarza } \\
\text { i ul. Nagłowicka }\end{array}$ & 2886 & gmina miejska & \multirow{2}{*}{$\begin{array}{l}\text { Dzielnica XV } \\
\text { Mistrzejowice }\end{array}$} \\
\hline Piastów & os. Piastów & 4176 & gmina miejska & \\
\hline Tomex & ul. Bieńczycka & 21588 & prywatny & \multirow{2}{*}{$\begin{array}{c}\text { Dzielnica XVI } \\
\text { Bieńczyce }\end{array}$} \\
\hline $\begin{array}{l}\text { Bieńczyce (Bieńczycki } \\
\text { Plac Targowy) }\end{array}$ & ul. Kocmyrzowska & 5730 & prywatny & \\
\hline $\begin{array}{l}\text { Bulwar (Mogilski Plac } \\
\text { Targowy) }\end{array}$ & os. Wandy & 4193 & gmina miejska & $\begin{array}{c}\text { Dzielnica XVIII } \\
\text { Nowa Huta }\end{array}$ \\
\hline
\end{tabular}

Źródło: opracowanie na podstawie Raportu o stanie miasta 2013 (2014) 
W ostatnich kilkunastu latach liczba targowisk oraz łączna powierzchnia sprzedażowa na placach targowych w Krakowie systematycznie maleją (tab. 2). Towarzyszy temu jednoczesny przyrost liczby super- i hipermarketów. Przykładowo, w latach 2009-2012 liczba supermarketów w granicach miasta Krakowa wzrosła z 66 do 88 (wzrost powierzchni sprzedażowej z 52,1 tys. $\mathrm{m}^{2}$ do 69,9 tys. $\mathrm{m}^{2}$ ), natomiast liczba hipermarketów zwiększyła się z 18 do 21 (wzrost powierzchni sprzedażowej z 161,3 tys. $\mathrm{m}^{2}$ do 177,7 tys. $\mathrm{m}^{2}$ ) (Rocznik Statystyczny Krakowa 2011, 2011).

Tab. 2. Liczba i powierzchnia sprzedażowa krakowskich placów targowych w latach 2000-2012

\begin{tabular}{|l|c|c|c|c|c|c|}
\hline \multicolumn{1}{|c|}{ Wyszczególnienie $^{*}$} & $\mathbf{2 0 0 0}$ & $\mathbf{2 0 0 5}$ & $\mathbf{2 0 0 9}$ & $\mathbf{2 0 1 0}$ & $\mathbf{2 0 1 1}$ & $\mathbf{2 0 1 2}$ \\
\hline Liczba targowisk stałych $^{2}$ & 33 & 18 & 17 & 17 & 16 & 16 \\
\hline $\begin{array}{l}\text { Powierzchnia } \\
\text { sprzedażowa targowisk } \\
\text { stałych }\left(\text { tys. } \mathrm{m}^{2}\right)\end{array}$ & 120,9 & 92,6 & 84,6 & 85,2 & 83,9 & 83,3 \\
\hline
\end{tabular}

*Dotyczy targowisk na terenach gminnych.

Źródło: Roczniki Statystyczne Krakowa z lat 2011 i 2012

Rozwój handlu wielkopowierzchniowego stanowi dla funkcjonowania palców targowych zasadniczą konkurencję, której handlujący na krakowskich targowiskach starają się opierać. Nie zawsze jednak skutecznie, gdyż jak wskazały badania przeprowadzone w ramach „CENTRAL MARKETS. Rewitalizacja i promocja tradycyjnych placów targowych w Europie Centralnej”, klientów na placach targowych Krakowa ubywa (www.centralmarkets.eu).

Władze miasta Krakowa doceniają rolę targowisk w kształtowaniu struktury miejskiej i specyficznej atmosfery miejsca w mieście o szczególnych walorach turystycznych. W 2013 r. podpisały umowę partnerską dotyczącą projektu „CENTRAL MARKETS. Rewitalizacja i promocja tradycyjnych placów targowych w Europie Centralnej”. Celem projektu były rewitalizacja, wzmocnienie i integracja placów targowych oraz partnerów projektu przez poszerzenie wiedzy, wprowadzenie innowacyjnych działań wynikających ze współpracy międzynarodowej. Projekt był finansowany ze środków Europejskiego Funduszu Rozwoju Regionalnego (European Regional Development Found - ERDF); Priorytet 4 - Podniesienie konkurencyjności oraz atrakcyjności miast i regionów; Działanie 4.1 - Rozwój policentrycznych struktur osadniczych oraz współpracy terytorialnej. W ramach projektu w 2013 r. zrealizowano m.in. badania ankietowe placów targowych wśród sprzedających i kupujących, zorganizowano pierwszą edycję Festiwalu Placów Targowych Krakowa „Krakowskim targiem”, która została oceniona pozytywnie przez spółki kupieckie zarządzające targowiskami, kupujących i media, przeprowadzono grę miejską o targowiskach „Krakowskim targiem”, w której udział wzięło ponad 200 uczestników, wykonano materiały promocyjne dla turystów krajowych i zagranicznych, w tym niestandardową propozycję zwiedzania placów w formie tzw. Questu - zwiedzanie połączone z rozwiązywaniem zagadek, zespół projektowy wziął udział w spotkaniach partnerów projektu w Peczu, Ustii i Turynie, prezentując Kraków i krakowskie rozwiązania w zakresie promowania targowisk i zarządzania nimi (www.centralmarkets.eu). Celem przystąpienia do projektu była przede wszystkim promocja krakowskich targowisk wśród mieszkańców i turystów.

Jak wskazały badania prowadzone w ramach projektu, na analizowanych placach targowych: Stary Kleparz, Nowy Kleparz, Plac na Stawach, Rynek Dębnicki, Hala Targowa, Plac 
Nowy dla kupujących niekoniecznie najważniejsza jest niska cena. Jest ona dla respondentów istotna, jednakże w połączeniu z jakością produktów i ich świeżością. Dla klientów placów bardzo ważne jest to, że znają osobiście rolnika, od którego kupują produkty, oraz fakt, że mogą z nim porozmawiać. Chcą mieć pewność, że to, za co płacą, rzeczywiście jest zdrowe i ekologiczne, a nie pochodzi z hurtowni (www.centralmarkets.eu).

\section{Metodologia badań własnych}

Badania empiryczne autorek niniejszej publikacji prowadzone były w wybranych miejscach Krakowa, a uczestniczyli w nich przede wszystkim mieszkańcy Krakowa. Łącznie wzięło w nich udział 502 respondentów dobranych metodą losową. Jako narzędzie badawcze wykorzystano metodę kwestionariusza wywiadu zawierającego łącznie 9 grup pytań. Badania rozpoczęto w okresie maj-czerwiec 2014 r. i kontynuowano do stycznia 2015 r. Kryterium doboru punktów przeprowadzenia wywiadów stanowiła duża liczba osób odwiedzających wyznaczone miejsca, jak również bliskie położenie względem analizowanych placów targowych (odległość do $1 \mathrm{~km}$ od wyznaczonego placu targowego). Badania odnosiły się do 22 placów targowych zlokalizowanych w granicach administracyjnych miasta Krakowa. Były to następujące place targowe: Stary Kleparz, Nowy Kleparz, Plac Targowy przy ul. Brodowicza, Hala Targowa, Plac Rydla, Manhattan, Beskidy, Złoty Wiek, Centrum Giełdowo-Handlowe Balicka, Plac Imbramowski, Rynek Dębnicki, Plac Nowowiejski, Jerzmanowskiego - Nowy Prokocim, Tandeta, Targowisko Borek, Plac Na Stawach, Mogilski Plac Targowy, Bieńczycki Plac Targowy, Tomex, Piastów, Złoty Wiek, Plac Targowy w os. Kalinowym. Należy zaznaczyć, że 2 place targowe: Plac Targowy przy ul. Brodowicza oraz Plac Targowy w os. Kalinowym oficjalnie, czyli zgodnie ze spisem Urzędu Miasta Krakowa, nie są traktowane jako targowiska. Jednakże są to nagromadzenia sklepów o fizjonomii targowiska, dlatego zostały uwzględnione w badaniach autorek.

Przeprowadzono również badania empiryczne mające na celu określenie preferencji respondentów w zakresie wyboru określonych form handlu oraz miejsca dokonywania zakupów. Prowadzono je na obszarze całego Krakowa, a uczestniczyło w nich łącznie 356 respondentów, w przeważającej większości będących mieszkańcami tego miasta. Próba badawcza dobrana została metodą losową, przy czym należy zwrócić uwagę, że kobiety znacznie chętniej uczestniczyły w badaniach niż mężczyźni.

\section{Atrakcyjność dokonywania zakupów na placach targowych Krakowa w opinii respondentów - wyniki badań}

Respondenci uczestniczący w badaniach w przeważającej większości byli mieszkańcami Krakowa (78\%). W 60\% były to kobiety, z dużym udziałem kobiet mających średnie wykształcenie (ponad 47\%).

Analizując preferencje respondentów w różnych grupach wiekowych w zakresie najczęściej wybieranych form handlu, zaobserwowano pewne prawidłowości. Im starsi byli respondenci, tym chętniej wybierali place targowe jako miejsce dokonywania zakupów (tab. 3). 
Tab. 3. Preferencje respondentów w poszczególnych grupach wiekowych w zakresie dokonywania zakupów według form handlu

\begin{tabular}{|c|c|c|c|c|c|c|c|c|}
\hline \multirow[b]{2}{*}{$\begin{array}{c}\text { Wiek } \\
\text { respondentów }\end{array}$} & \multirow[b]{2}{*}{$\begin{array}{c}\text { Liczba } \\
\text { respondentów } \\
(\mathrm{N}=356)\end{array}$} & \multicolumn{7}{|c|}{ Preferencje respondentów według form handlu (\%) } \\
\hline & & 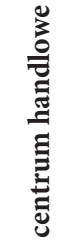 & 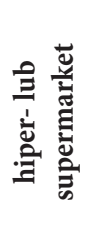 & 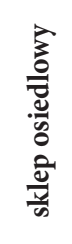 & 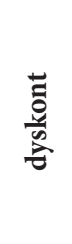 & & 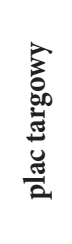 & 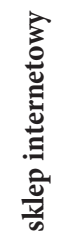 \\
\hline $16-20$ & 34 & 50,0 & 23,5 & 8,8 & 29,4 & 5,9 & 2,9 & 64,7 \\
\hline $21-30$ & 119 & 63,9 & 42,9 & 22,7 & 42,0 & 8,4 & 18,5 & 51,3 \\
\hline $31-40$ & 84 & 70,2 & 51,2 & 32,1 & 47,6 & 2,4 & 21,4 & 47,6 \\
\hline $41-50$ & 46 & 56,5 & 26,1 & 52,2 & 60,9 & 13,0 & 34,8 & 19,6 \\
\hline $51-60$ & 39 & 25,6 & 28,2 & 64,1 & 51,3 & 7,7 & 53,8 & 2,6 \\
\hline powyżej 60 lat & 34 & 11,8 & 14,7 & 70,6 & 29,4 & 2,9 & 64,7 & 2,9 \\
\hline
\end{tabular}

Źródło: opracowanie własne na podstawie uzyskanych wyników badań

Jak wcześniej zasygnalizowano, autorki przeprowadziły osobne badania dotyczące wyłącznie placów targowych. Spośród 502 respondentów uczestniczących w tych badaniach niemal 66\% dokonuje zakupów właśnie na placach targowych. Ankietowani pytani o przyczyny dokonywania tam zakupów najczęściej jako powód podawali większą dostępność świeżych produktów $(68,5 \%)$, niższe ceny $(55,2 \%)$ oraz bezpośredni kontakt ze sprzedawcą $(37,9 \%)$. Konsumenci cenią sobie wysoką jakość nabywanych produktów oraz bezpośredni kontakt ze sprzedawcą, który może poinformować o pochodzeniu produktu, i z którym można też bezpośrednio uzgodnić ostateczną cenę.

Ryc. 1. Przyczyny dokonywania zakupów na placach targowych Krakowa

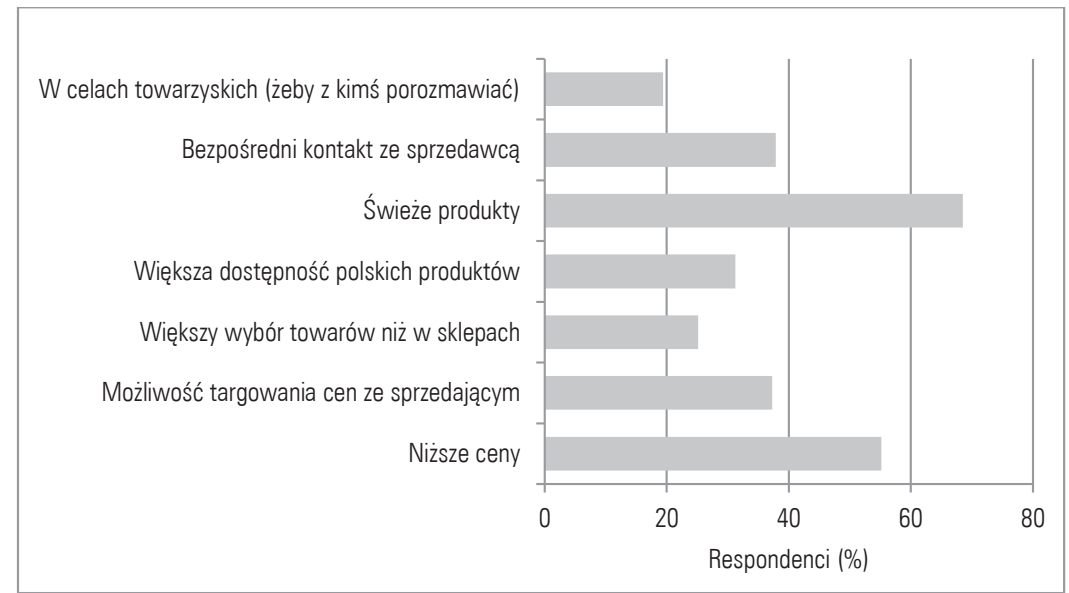

Źródło: opracowanie własne na podstawie uzyskanych wyników badań 


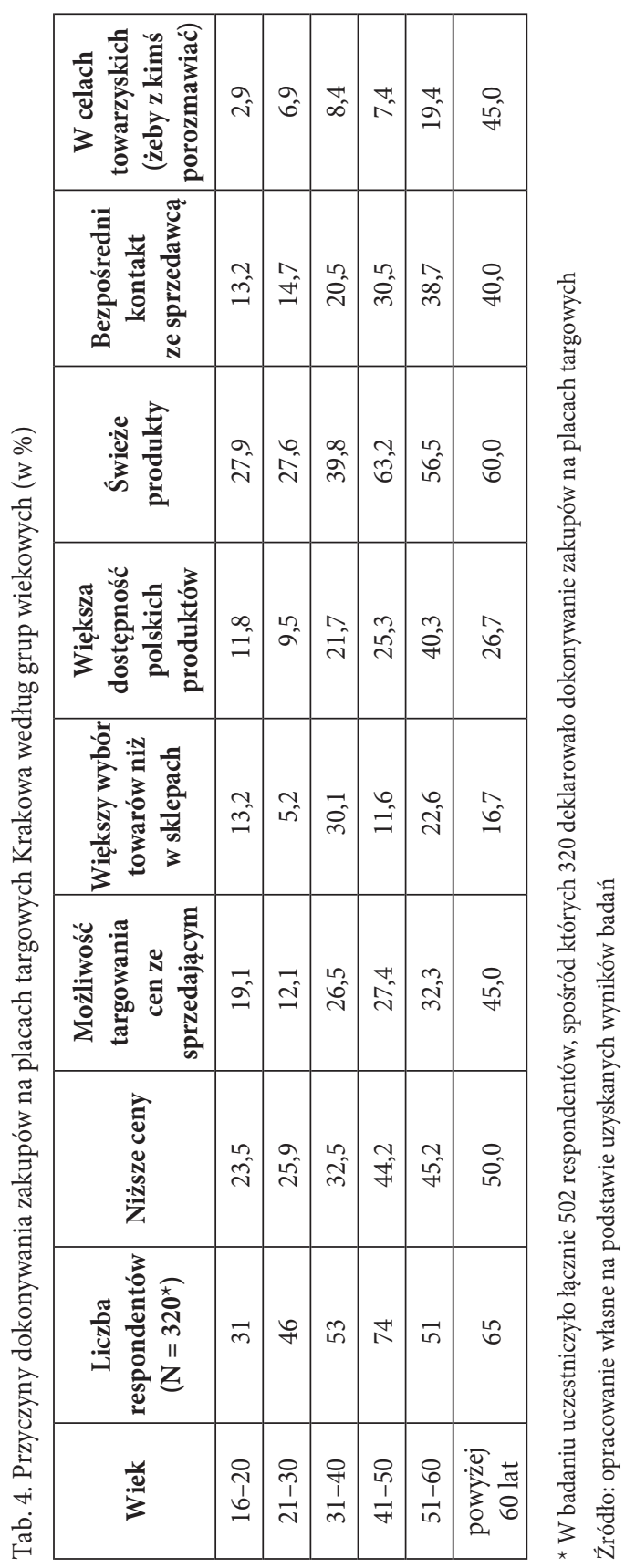


Ryc. 2. Przyczyny niepodejmowania decyzji o zakupach na placach targowych Krakowa

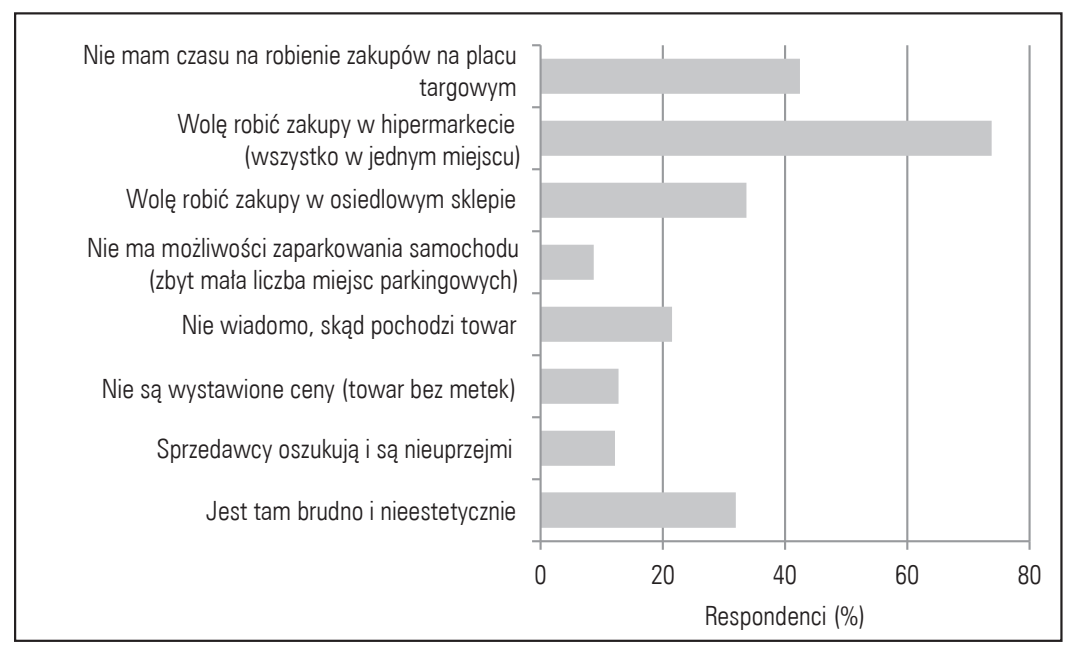

Źródło: opracowanie własne na podstawie uzyskanych wyników badań

Ryc. 3. Częstotliwość dokonywania zakupów na placach targowych Krakowa

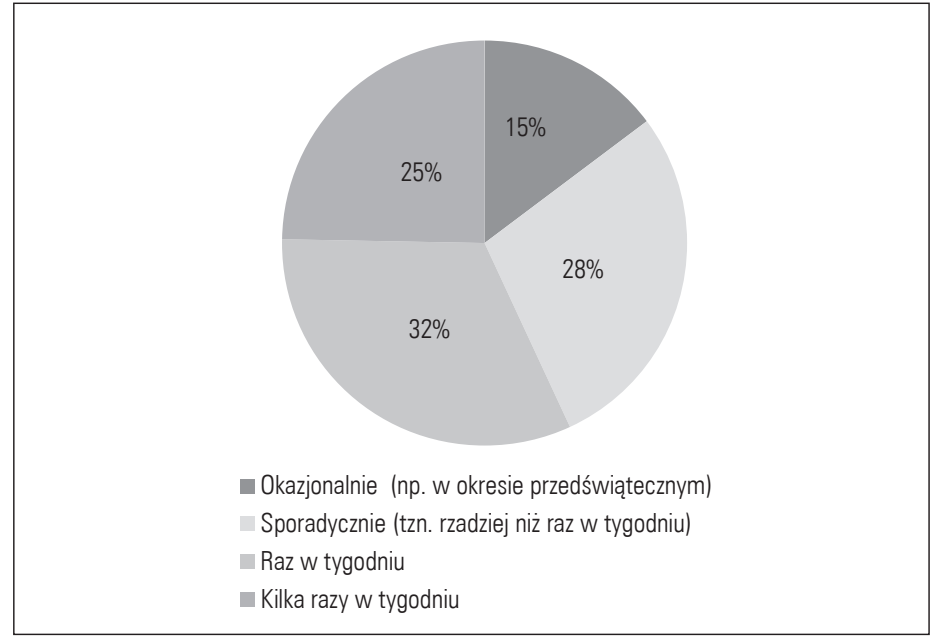

Źródło: opracowanie własne na podstawie uzyskanych wyników badań

Analiza przyczyn dokonywania zakupów w poszczególnych grupach wiekowych wykazała, że respondenci mający 51-60 lat i powyżej 60 lat w największym stopniu doceniają walory placów targowych. Szczególnie zwracają oni uwagę na świeżość produktów dostępnych na placach (odpowiednio 56,5\% i 60,0\%), niskie ceny $(45,2 \%$ i 50,0\%) oraz bezpośredni kontakt ze sprzedawcą (38,7\% i 40,0\%). Respondenci w wieku 51-60 lat zwracają również uwagę na większą dostępność polskich produktów na placach targowych.

Nieco ponad 34\% respondentów deklaruje, że nie odwiedza placów targowych. Wolą oni zazwyczaj dokonywać zakupów w hipermarkecie, gdzie w jednym miejscu mają dostęp do 


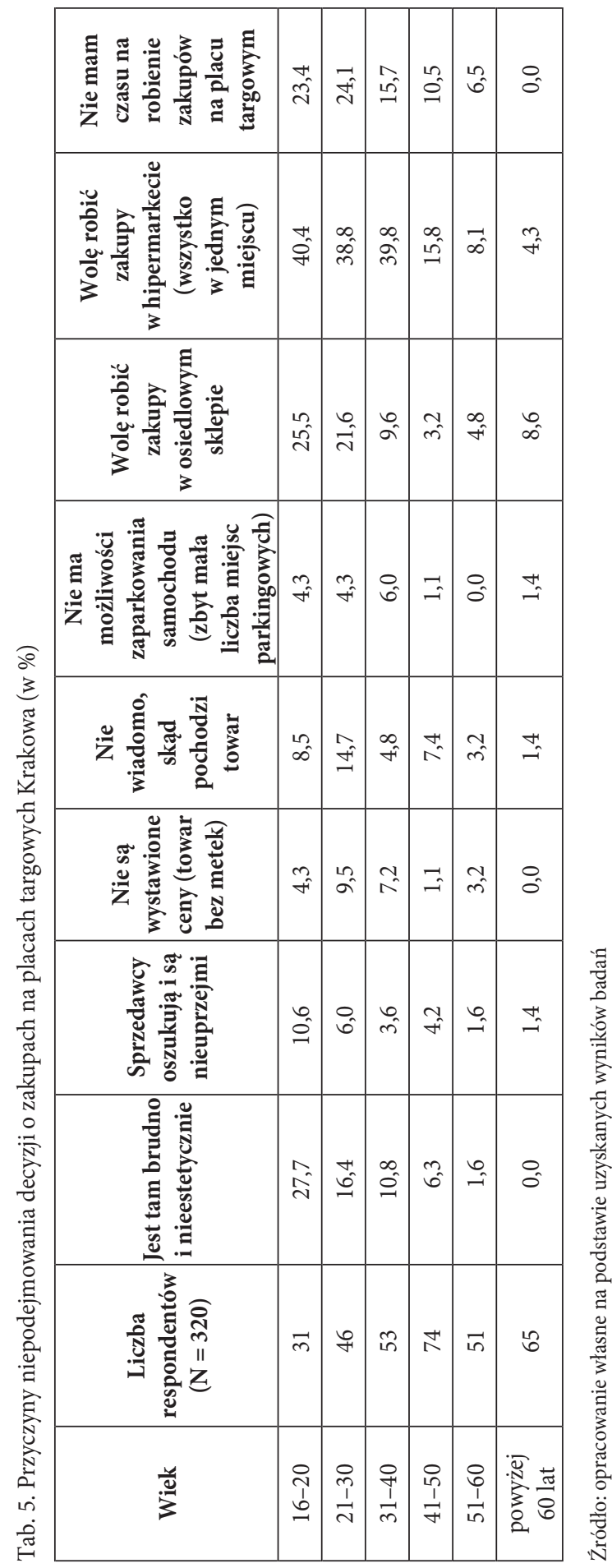


Ryc. 4. Produkty najczęściej kupowane na targowiskach Krakowa

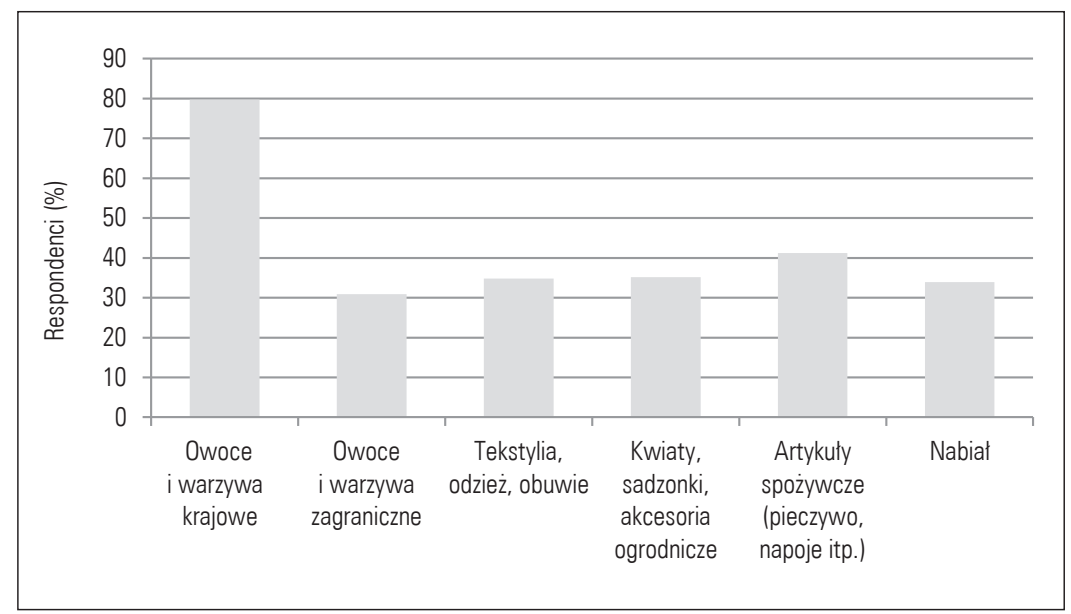

Źródło: opracowanie własne na podstawie uzyskanych wyników badań

Ryc. 5. Jak zmieniły się place targowe Krakowa według respondentów

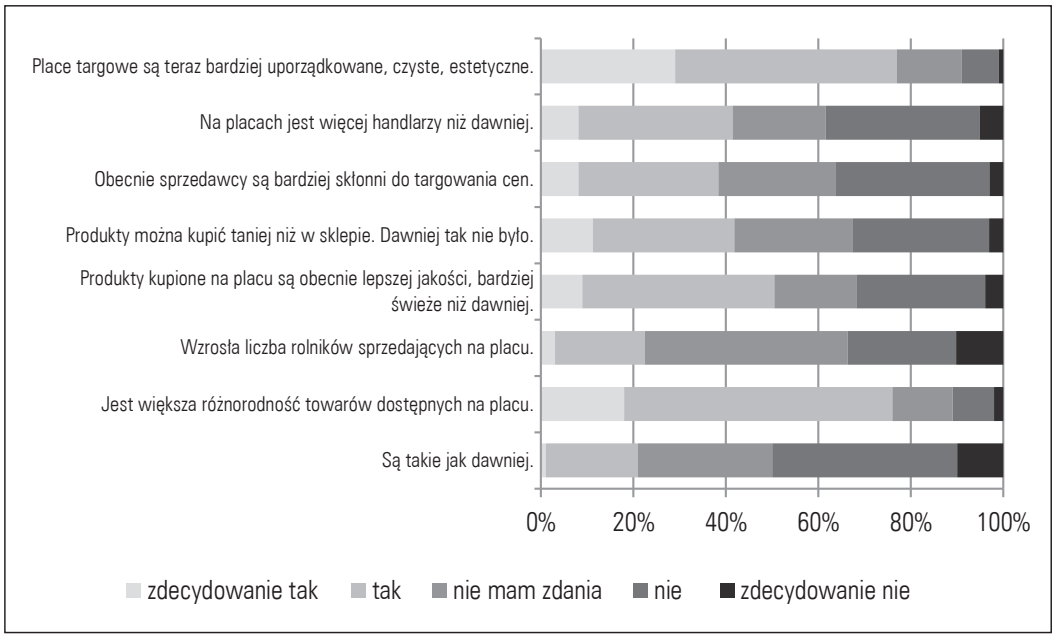

Źródło: opracowanie własne na podstawie uzyskanych wyników badań

produktów, które są im niezbędne (73,8\%), nie mają czasu na zakupy na targowiskach $(42,4 \%)$ lub też wolą osiedlowe sklepy $(33,7 \%)$. Respondenci ci cenią sobie przede wszystkim wygodę i oszczędność czasu.

Analiza przyczyn rezygnacji respondentów w poszczególnych grupach wiekowych z dokonywania zakupów na placach targowych wykazała, że z tej formy handlu przede wszystkim nie korzystają osoby młode - grupy wiekowe 16-20 lat oraz 21-30 lat. Respondenci ci preferują zakupy w hipermarkecie (odpowiednio 40,4\% i 38,8\%) lub sklepie osiedlowym (25,5\% i 21\%). Zwracają również uwagę na fakt, iż na placach targowych jest brudno i nieestetycznie (27,7\% i 16,4\%). 
Niespełna $60 \%$ respondentów twierdzi, że dokonuje zakupów na placach targowych regularnie, przynajmniej raz w tygodniu, natomiast nieco ponad $40 \%$ robi to okazjonalnie lub sporadycznie. Można stąd wnioskować, że osoby deklarujące korzystanie z placów targowych jako miejsca dokonywania zakupów, robią to często i systematycznie.

Produkty zdecydowanie najczęściej nabywane na placach targowych to owoce i warzywa krajowe (79,9\%). Natomiast w mniejszym stopniu - artykuły spożywcze, jak np. pieczywo, napoje itp. $(41,2 \%)$, a także kwiaty, sadzonki, akcesoria ogrodnicze, tekstylia $(35,2 \%)$ oraz odzież i obuwie $(34,8 \%)$.

Respondenci dokonali oceny, jak zmienił się plac targowy w ostatnich latach. Ich zdaniem obecnie ,jest większa różnorodność towarów dostępnych na placu” (73,3\%), „plac targowy jest teraz bardziej uporządkowany, czysty, estetyczny” (67,0\%), a „produkty kupione na placu są obecnie lepszej jakości, świeższe niż dawniej” (53,9\%).

\section{Podsumowanie}

Place targowe od dawna stanowią nierozerwalny fragment przestrzeni miejskiej. Współcześnie handel na nich odbywa się właściwie codziennie, a różnorodność oferowanych produktów jest bardzo duża. Handlem na placach trudnią się już nie tylko rolnicy sprzedający swoje płody rolne czy rzemieślnicy sprzedający swoje wyroby. Coraz częściej znajdują się tam również stałe, zadaszone stragany lub hale ze stoiskami, a także małe sklepy, w których odbywa się handel, prowadzony niekoniecznie przez właścicieli lub najemców obiektów, ale również przez pracowników najemnych.

W Krakowie funkcjonuje obecnie 27 targowisk zróżnicowanych zarówno pod względem powierzchni, okresu funkcjonowania, jak i formy własności gruntu, na którym się znajdują. Badania empiryczne przeprowadzone na potrzeby niniejszego opracowania objęły swoim zasięgiem 22 place targowe zlokalizowane w granicach administracyjnych miasta Krakowa i prowadzone były w wyznaczonych miejscach miasta charakteryzujących się określonym położeniem.

Uzyskane wyniki badań przyczyniły się do udzielenia odpowiedzi na dwa postawione na wstępie pytania badawcze. W pierwszym zapytano o wpływ struktury wieku respondentów na preferencje zakupowe w zakresie najczęściej wybieranych form handlu. Przeprowadzone analizy dowodzą, że taki wpływ istnieje. Osoby starsze zdecydowanie częściej preferują tradycyjne formy handlu, jakimi są prace targowe czy sklepy osiedlowe. Na placach targowych cenią sobie one przede wszystkim świeżość dostępnych produktów, niskie ceny oraz bezpośredni kontakt ze sprzedawcą. Respondenci w wieku 51-60 lat zwracają również uwagę na większą dostępność na placach targowych produktów pochodzenia krajowego.

Pytanie drugie dotyczyło powodów (czynników) wyboru placów targowych jako miejsca dokonywania zakupów (lub braku tego wyboru) wśród respondentów. Respondenci uczestniczący w badaniach, bez względu na wiek, najczęściej podkreślali większą dostępność świeżych produktów, niższe ceny oraz bezpośredni kontakt ze sprzedawcą, który może poinformować o pochodzeniu produktu, i z którym bezpośrednio można uzgodnić ostateczną cenę.

Na podstawie uzyskanych wyników badań można stwierdzić, że głównymi przesłankami towarzyszącymi zakupom na placach targowych są dwa czynniki: aspekt zdrowotny (megatrend $\mathrm{w}$ zachowaniach konsumentów polegający na coraz większej koncentracji na zdrowym odżywianiu), jak również aspekt ekonomiczny - co podkreślano już we wcześniejszych 
badaniach (Płaziak, Szymańska, 2014; Płaziak, Szymańska, 2015a). Klienci placów targowych szukają nie tylko produktów świeżych, zdrowych i produkowanych niehurtowo, ale także tanich, co jest szczególnie ważne w przypadku osób starszych, stanowiących 36\% wszystkich odwiedzających place targowe.

Literatura

References

Barek, R. (2010). Targowisko - przestrzeń niezbędna w środowisku zamieszkiwania. Czasopismo Techniczne. Architektura, 107, 5, 9-14.

CENTRAL MARKETS. Rewitalizacja i promocja tradycyjnych placów targowych w Europie Centralnej (2015, 16 listopada). Pozyskano z: www.centralmarkets.eu.

Ciechomski, W. (2014). Handel targowiskowy w Poznaniu - diagnoza stanu rozwoju, preferencje klientów, tendencje zmian. Zeszyty Naukowe, 28, Wydawnictwo Naukowe Wyższej Szkoły Handlu i Usług w Poznaniu, 25-46.

Dąbrowski, J.M. (1996). Handel targowiskowy fenomen polskiej transformacji. Warszawa: Instytut Badań nad Gospodarką Rynkową.

Dziechciarz, T. (1992a). Zróżnicowanie cen na placach targowych miasta Krakowa. Prace Instytutu Geografii UJ. Prace Geograficzne, 91.

Dziechciarz, T. (1992b). Funkcjonowanie handlu na placach targowych na przykładzie Placu Nowego w Krakowie. Folia Geographica, Series Geographica-Oeconomica, XXV-XXVI, 81-91.

Dzieszyński R., Franczyk J.L. (2006). Encyklopedia Nowej Huty, Wydawnictwo Towarzystwa Słowaków w Polsce, współpraca: Głos - Tygodnik Nowohucki, Kraków: Nowohuckie Centrum Kultury.

Gołąb-Korzeniowska, M. (1995). Place handlowe w strukturze miejskiej Krakowa. Zeszyty Naukowo-Dydaktyczne Instytutu Projektowania Miast i Regionów 1994/95.

Gołąb-Korzeniowska, M. (1997). Rola i znaczenie placów handlowych w strukturze przestrzennej miasta na przykładzie Krakowa, praca doktorska, Biblioteka Cyfrowa Politechniki Krakowskiej.

Kropiwnicki, J. (2003). Fenomen bazarów. Folia Oeconomica, 170, Acta Universitatis Lodziensis.

Peterlik, M., (2000). Handel targowiskowy w Polsce w 1999 roku. Warszawa: Instytut Badań nad Gospodarką Rynkową.

Płaziak, M., Szymańska, A.I. (2014). Rola placów targowych w strukturze przestrzenno-społecznej i ekonomicznej Nowej Huty. W: E. Kaczmarska, P. Raźniak (red.), Społeczno-ekonomiczne i przestrzenne przemiany struktur regionalnych. Kraków: Oficyna Wydawnicza AFM, 91-108.

Płaziak, M., Szymańska, A.I. (2015a). Postawy ludzi młodych wobec innowacji a prosumeryzm. Na przykładzie studentów uczelni krakowskich, Logistyka, 2, 1028-1038.

Płaziak, M., Szymańska, A.I. (2015b). Uwarunkowania działalności przedsiębiorców i rolników na placach targowych na przykładzie Nowej Huty. Przedsiębiorczość - Edukacja, 11, 203-217.

Powęska, H. (1995). Development of trade and services in the eastern borderland of Poland - Problems and prospects. Polish Eastern Border. Past and Present Problems, Conference Papers, 22, Warszawa: IGiPZ PAN, 83-96.

Powęska, H. (2002a). Przestrzenny wymiar handlu targowiskowego w województwie małopolskim w 2000 r. W: Z. Górka, A. Jelonek (red.), Geograficzne uwarunkowania rozwoju Małopolski. Kraków: Instytut Geografii i Gospodarki Przestrzennej UJ, 413-416.

Powęska, H. (2002b). Przestrzenny wymiar handlu transgranicznego w Polsce w ostatniej dekadzie XX wieku, Geopolitical Studies, 9.

Raport o stanie miasta 2013. (2014). Prezydent Miasta Krakowa, Kraków.

Rynek wewnętrzny w 2012 r. (2013). Informacje i opracowania statystyczne. Warszawa: Główny Urząd Statystyczny.

Rocznik Statystyczny Krakowa 2011. (2011). Kraków: Urząd Statystyczny w Krakowie.

Rocznik Statystyczny Krakowa 2012. (2012). Kraków: Urząd Statystyczny w Krakowie. 
Rocznik Statystyczny Krakowa 2013. (2013). Kraków: Urząd Statystyczny w Krakowie.

Szafrański, D. (2002). Administracyjnoprawna regulacja działalności gospodarczej o Okresie II Rzeczypospolitej. Studia Iuridica, Xl, 231-244.

Szromba-Rysowa, Z. (1993). Targowisko „Stary Kleparz” - targ w lokalnej kulturze społecznej. W: J. Bujak i in. (red.), Kraków. Przestrzenie kulturowe. Kraków: Platan.

Tomalak, M., Wyżnikiewicz, B. (1999). Handel targowiskowy w 1998 roku. Warszawa: Instytut Badań nad Gospodarką Rynkową.

Urban, S., Michałowska, M. (2013). Czynniki wpływające na zachowania konsumentów w zakresie wyboru targowisk jako miejsca zakupu produktów konsumpcyjnych na przykładzie województwa lubuskiego. Roczniki Ekonomii Rolnictwa i Rozwoju Obszarów Wiejskich, 100(2), 108-118.

Werwicki, A. (2001). Handel targowiskowy Aglomeracji Łódzkiej na tle jego znaczenia ogólnopolskiego w latach 1994-1997. Łódź: ŁTN.

Wojdacki, K.P. (2011). Przestrzenne aspekty rozwoju handlu targowiskowego w Polsce. Handel Wewnętrzny, 6, 23-35.

Zuzańska-Żýśko, E., Sitek, S. (2011). Rola handlu targowiskowego w rozwoju miast. W: M. Soja, A. Zborowski (red.), Człowiek w przestrzeni zurbanizowanej. Kraków: Instytut Geografii i Gospodarki Przestrzennej UJ, 271-281.

Monika Płaziak, dr, adiunkt, Uniwersytet Pedagogiczny im. Komisji Edukacji Narodowej w Krakowie, Instytut Geografii, Zakład Przedsiębiorczości i Gospodarki Przestrzennej. Zainteresowania badawcze autorki dotyczą zagadnień gospodarki przestrzennej w kontekście czynników lokalizacji przedsiębiorstw, szczególnie czynnika personalnego. Prace badawcze odnoszą się również do zagadnień współpracy jednostek naukowych i badawczo-rozwojowych z sektorem MŚP, zwłaszcza w zakresie wdrażania nowych technologii i materiałów, w tym dotyczących budownictwa energooszczędnego i pasywnego. Ponadto autorka zajmuje się problematyką poziomu i jakości życia ludności, ze szczególnym uwzględnieniem małych i średnich miast Polski oraz miast postsocjalistycznych.

Monika Płaziak, PhD, Pedagogical University of Cracow, Institute of Geography, Department of Entrepreneurship and Spatial Management. Author's research interests concern issues of the spatial development in the context of location factors of enterprises, especially - personal factor. Research works also refer to issues of the cooperation of scientific and research-developmental organizations with the sector of small and medium-sized enterprises, especially in the matter of the implementing new technologies and materials concerning the energy-efficient and passive building. Additionally, the author analyses issues of the level and quality of life, with particular reference to small and medium-sized towns in Poland, and post socialist towns.

Anna Irena Szymańska, dr, Uniwersytet Pedagogiczny im. Komisji Edukacji Narodowej w Krakowie, Zakład Przedsiębiorczości i Gospodarki Przestrzennej. Absolwentka studiów z zakresu zarządzania i marketingu Uniwersytetu Ekonomicznego w Krakowie, doktor nauk ekonomicznych w zakresie nauk o zarządzaniu (Katedra Analizy Rynku i Badań Rynkowych - Uniwersytet Ekonomiczny w Krakowie). Adiunkt w Zakładzie Przedsiębiorczości i Gospodarki Przestrzennej Uniwersytetu Pedagogicznego w Krakowie. Zainteresowania badawcze oscylują wokół problematyki potrzeb, preferencji i zachowań rynkowych konsumentów, jak również zagadnień z obszaru przedsiębiorczości i innowacyjności przedsiębiorstw ze szczególnym uwzględnieniem sektora MŚP.

Anna Irena Szymańska, PhD, Pedagogical University of Cracow, Institute of Geography, Department of Entrepreneurship and Spatial Management. Anna Irena Szymańska graduated from the University of Economics in Cracow, MA degree in Management and Marketing, $\mathrm{PhD}$ degree in economic sciences in the field of management sciences (Chair of Market Analysis and Marketing Research - University of Economics in Cracow). Adjunct in the Department of Entrepreneurship and Spatial Management at Pedagogical University of Cracow. Her research interests are related to the issue of consumer needs, preferences and market behavior as well as issues in the area of entrepreneurship and innovation with particular emphasis on the SME sector. 
Adres/Address:

Uniwersytet Pedagogiczny im. Komisji Edukacji Narodowej w Krakowie Instytut Geografii

Zakład Przedsiębiorczości i Gospodarki Przestrzennej

ul. Podchorążych 2

30-084 Kraków, Polska

e-mail:mplaziak@up.krakow.pl

e-mail: aszym@up.krakow.pl 